\title{
Kohor retrospective study: development of children age 1-3 year with history of low born weigh (LBW) infants
}

\author{
Heni Puji Wahyuningsih a,b, I* Indah Ajeng Pramesti a, ${ }^{2}$, Endah Marianingsih Theresia a, 3 \\ a Midwifery Department, Poltekkes Kemenkes Yogyakarta, Mangkuyudan Street, MJIII/304 Yogyakarta, 55143 \\ ${ }^{b}$ PUI Novakesmas, Poltekkes Kemenkes Yogyakarta, Tata Bumi Street No 3, Sleman, 55293 \\ ${ }^{1}$ heni.pujiw@poltekkesjogja.ac.id*; indahajengpramesti@yahoo.com; endahmth@gmail.com \\ *korespondensi penulis
}

\begin{tabular}{ll}
\hline \multicolumn{2}{l}{ Article information: } \\
\hline Article history: & \\
Accepted & : March $5^{\text {th } 202 I}$ \\
Revised & $:$ March $7^{\text {th }} 202 \mathrm{I}$ \\
Published & $:$ March $8^{\text {th }} 202 \mathrm{I}$
\end{tabular}

\section{Key word: \\ LBW}

Development

Toddlers

\begin{abstract}
Low Born Weigh (LBW) is a baby with birth weight $<2500$ grams. LBW babies are weak in fine motor skills. If toddlers' developmental disorders are not detected early it will affect the quality of life, showed the prevalence of LBW in by $5.52 \%$. The prevalence of LBW infants in Bantul Regency from 2014 to 2018 has increased. The highest LBW cases were in the Pleret Puskesmas which reached $6.23 \%$. The high prevalence of LBW in Pleret District, has made researchers interested in conducting research on the relationship of LBW history with the development of toddlers aged 1-3 years. The purpose of this research is to find out the influence of LBW history with the development of toddlers aged 1-3 years. This type of research is an observational analytic study with a retrospective cohort design. The sample in this study is toddlers aged 1-3 years in the district of Pleret. The independent variables of this study were the birth weight of infants and the dependent variable of development of infants aged 1-3 years. Statistical tests use the Chi-square test and relative risk. This research shows that as many as $31 \%$ of children under five with a history of LBW had inappropriate development status. The chi-square test showed a pvalue of $0.016(<0.05)$ which meant that there was a significant relationship between LBW history and the developmental status of toddlers. Obtained RR value of 1,250 (>1,00), shows that toddlers with a history of LBW have a risk of experiencing developmental disorders 1.25 times greater than toddlers with normal weight history. Conclusion of this research is a there is a significant relationship between LBW history and the development of toddlers aged 1-3 years. Toddlers with an LBW history have a greater risk of developing developmental disorders compared to toddlers with with normal weight history.
\end{abstract}

This is an openaccess article under the CC-BY-SA license.

\section{Introduction}

Low birth weight babies (LBW) is a newborn with birth weight less than 2500 grams (up to 2499 grams). LBW can be caused by many factors including maternal factors, overworked factors, pregnancy factors, fetal factors, and unknown factors. ${ }^{1}$ According to WHO in 2015 there was $15.5 \%$ LBW incidence, meaning that around 20.6 million babies were born LBW every year, $96.5 \%$ of them in developing countries. ${ }^{2}$ Babies with low birth weight have the potential to experience sensory disorders, central nervous system motor disorders, 
hydrocephalus, and cerebral paralysis. ${ }^{3}$ Globally every year more than 200 million children aged less than 5 years show developmental delays and $86 \%$ occur in developing countries. ${ }^{4}$ Approximately $5-10 \%$ of children in Indonesia are estimated to experience developmental delays including motor, language, socio-emotional, and cognitive development. ${ }^{5}$ Based on 2018 Riskesdas data the prevalence of LBW in Indonesia is 6.2\%, whereas in the Province of DIY the prevalence of LBW is $8.2 \% .^{6}$ This shows that the prevalence of LBW in DIY Province is higher than the national LBW prevalence.

DIY Health Profile in 2018 showed the prevalence of babies with LBW in DIY Province in 2018 of 5.52\%. The prevalence of LBW infants in Bantul Regency from 2014 to 2018 has increased every year. In 2016 the prevalence of LBW in Bantul Regency was 3.66\%, in 2017 it increased to $3.79 \%$, and in 2018 it increased to $3.81 \%$. LBW cases are found in all working areas of Health Care throughout Bantul Regency. The highest LBW cases were in the work area of the Pleret Health Care, which reached $6.23 \%{ }^{4}$

LBW infants increase the risk of developing cerebral palsy, which is a motor developmental disorder related to the ability to walk, and when compared to term infants, LBW infants are weak in fine motor skills such as breaking down threads. ${ }^{8}$ Development is the increase in abilities in the structure and function of the body that is more complex in a regular and predictable pattern as a result of the maturation process. This concerns the process of differentiation of body cells, body tissues, organs, and organ systems that develop in such a way that each one fulfills its function. Including the development of emotions, intellectuals, and behavior as a result of interaction with the environment. ${ }^{9}$

DDST II test results in infants aged 12-24 months in the Growth and Development Clinic RSUP DR. Sardjito from January to July 2015 there were $74.55 \%$ of them experiencing delays in personal social development $5.35 \%$, delays in fine motorcycles $9.11 \%$, delays in languages $26.73 \%$ and $43.85 \%$ experienced gross motor delays. ${ }^{10}$

The first three years period is a very important period in the fastest growth and development of the human brain. This period is the "Golden Period" (Golden Period), window of opportunity (Window Opportunity) as well as a critical period (Critical Period) for the child's brain in accepting various input/learning/influences from the environment around them that are both positive and negative. Stunted development in children caused by a lack of early detection of growth and development, will result in children less able to adjust and perform daily tasks. In fact, in the end, it can hamper children's academic development. Developmental failure at the age of five is a predictor of failure at later stages which results in a poor quality of life. ${ }^{9}$

The results of research conducted by Maryuni, 2017 stated that children born with LBW are at risk for developmental disorders 5.2 times greater than in children born at a normal weight. ${ }^{10}$ While research conducted by Ramadhan, 2016 with the title "Relationship History of Breastfeeding and Birth Weight with Gross Motoric Development and Fine Motoric Development of Infants 6-12 Months" shows that there is no relationship between birth weight with gross and fine motor development with a value of $p>0.05 .{ }^{12}$ This study was conducted to determine the significance of the relationship of LBW history with the status of development in toddlers aged 1-3 years at Pleret Bantul Health Center. The benefit of this research is that it can add empirical evidence and insight into the relationship of LBW history with development in toddlers aged 1-3 years. 


\section{Material and method}

This type of research is analytic observational research. The design in this study used a retrospective cohort. A retrospective cohort is an observational analytic study that identifies risk factors and effects on a cohort that occurred in the past, research conducted when an outcome has occurred..$^{13}$ The population in this study is toddlers in the Pleret Bantul Health Care area. While the samples in this study were toddlers aged 1-3 years in the area of Pleret Bantul Health Care which consisted of exposed sample groups, namely toddlers with a history of Low Birth Weight (LBW) totaling 70 respondents and an unexposed sample group namely infants with a history of Infant normal weight with 70 respondents. The sampling technique in this study used a purposive sampling technique. 140 Samples are taken to fulfill the inclusion and exclusion criteria. The inclusion criterion in this study is that subjects are willing to be respondents while the exclusion criteria in this study are toddlers with congenital defects. The study was conducted from March to April 2020 in the Pleret Public Health Center, Bantul. The data is obtained through a Google form distributed to respondents. Data processing techniques are done by editing, data entry, coding, and tabulating. The analysis in this study uses descriptive analysis, bivariate analysis, and multivariate analysis. The bivariate analysis uses a chi-square test and relative risk test, whereas in the multivariate analysis it uses a logistic regression test and path analysis.

\section{Result and discussion}

Descriptive analysis produces a frequency distribution and percentage of each selected variable, namely according to the incidence of LBW, child development, and gender characteristics, maternal education, maternal income and maternal nutritional status during pregnancy.

Table 1. Variable Frequency Distribution Based on LBW and Normal Weight Groups

\begin{tabular}{|c|c|c|c|c|c|c|c|c|}
\hline \multirow[t]{2}{*}{ No } & \multirow[t]{2}{*}{ Variable } & \multicolumn{2}{|l|}{ LBW } & \multicolumn{2}{|c|}{$\begin{array}{l}\text { Normal } \\
\text { Weight }\end{array}$} & \multicolumn{2}{|l|}{ Total } & \multirow[t]{2}{*}{ Sig. } \\
\hline & & $\mathrm{n}=70$ & $\%$ & $n=70$ & $\%$ & $\mathrm{n}=140$ & $\%$ & \\
\hline \multirow[t]{3}{*}{1} & Toddler Development Status & & & & & & & \multirow{3}{*}{0.001} \\
\hline & Appropriate & 48 & 68.6 & 60 & 85.7 & 108 & 77.1 & \\
\hline & Inappropriate & 22 & 31.4 & 10 & 14.2 & 32 & 22.9 & \\
\hline \multirow[t]{3}{*}{2} & Gender & & & & & & & \multirow{3}{*}{0706} \\
\hline & Women & 33 & 47.1 & 44 & 62.8 & 77 & 55 & \\
\hline & Male & 37 & 52.8 & 26 & 37.1 & 63 & 45 & \\
\hline \multirow[t]{3}{*}{3} & Maternal education level & & & & & & & \multirow{3}{*}{0.000} \\
\hline & High & 47 & 67.1 & 63 & 90 & 110 & 78.5 & \\
\hline & Low & 23 & 32.8 & 7 & 10 & 30 & 21.4 & \\
\hline \multirow[t]{3}{*}{4} & Parents ' income & & & & & & & \multirow{3}{*}{0.000} \\
\hline & High & 68 & 97.1 & 70 & 100 & 138 & 98.5 & \\
\hline & Low & 2 & 2.8 & 0 & 0 & 2 & 1.4 & \\
\hline \multirow[t]{3}{*}{5} & $\begin{array}{l}\text { Nutritional Status of mothers } \\
\text { during pregnancy }\end{array}$ & & & & & & & \multirow{3}{*}{0.029} \\
\hline & Non-Chronic Lack of Energy & 47 & 67.1 & 57 & 81.4 & 104 & 74.2 & \\
\hline & Chronic Lack of Energy & 23 & 32.8 & 13 & 18.5 & 36 & 25.7 & \\
\hline
\end{tabular}


Based on table 1, it is known that most of the children under five have appropriate development status, namely 108 infants $(77.1 \%)$ and 32 infants (22.9\%) have inappropriate development status. As many as $31 \%$ of children under five with a history of LBW have inappropriate development status. The sexes between men and women are almost the same, namely 77 women (55\%) and 63 boys (45\%). Mother's education for toddlers is mostly in the high category with 110 subjects $(78.6 \%)$ while in the low category there are 30 subjects $(21.4 \%)$. The income of toddlers' parents is mostly included in the high category with a total of 138 $(98.6 \%)$ while those in the low category only amounted to $2(1.4 \%)$. While the nutritional status of mothers during pregnancy most of them are not chronic lack of energy with the number $104(74.3 \%)$ and the rest are chronic lack of energy with a total of $36(25.7 \%)$. Homogeneity analysis results show that the status of development, level of education of mothers, the income of parents, and the nutritional status of mothers during pregnancy are homogeneous data, while gender is not homogeneous.

Based on table 1, toddlers aged 1-3 years with a history of LBW experienced the status of inappropriate development of 22 toddlers (31.4\%). Whereas toddlers with a history of BBLN experiencing development status did not match as many as 10 toddlers (14.3\%). Chisquare test results showed a p-value of $0.016(<0.05)$, which means there is a significant relationship between birth weight with the status of the development of infants. get a RR value of $1,250(>1.00)$, this shows that toddlers with a history of low birth weight have a risk of experiencing developmental disorders 1.25 times higher than toddlers who have a history of normal birth weight. This is consistent with the results of the study of Scharf et al (2016) which says that children born with a history of low birth weight have a tendency to experience developmental problems later in life. That is because babies with low birth weight are more susceptible to infectious diseases so that it will have an impact on the process of growth and development. ${ }^{15}$ Research conducted by Chapakia (2016) found similar results that skills in children with LBW history tend to be inhibited. The P-value obtained is 0.007 , meaning that there is a relationship between the history of birth weight with the child's motor development. ${ }^{11}$ Likewise, research conducted by Suratih, et al (2017) found that there was a relationship between children with LBW history with impaired child development with pvalue $0.019(<0.05) .{ }^{16}$ The development of toddlers is greatly influenced by the condition of body weight at birth. Children born with LBW are at risk of experiencing problems in their development. ${ }^{17}$ Babies with low birth weight have the potential to experience sensory disorders, central nervous system motor disorders, hydrocephalus, and cerebral paralysis. ${ }^{3}$ LBW babies increase the risk of motor developmental disorders related to the ability to walk, and when compared to normal babies, LBW babies are weak in fine motor skills such as breaking down threads. ${ }^{8}$

Table 2. Differences in Toddler Development by Birth Weight, Gender, Mother's Education Level, Parental Income, and Mother's Nutritional Status During Pregnancy

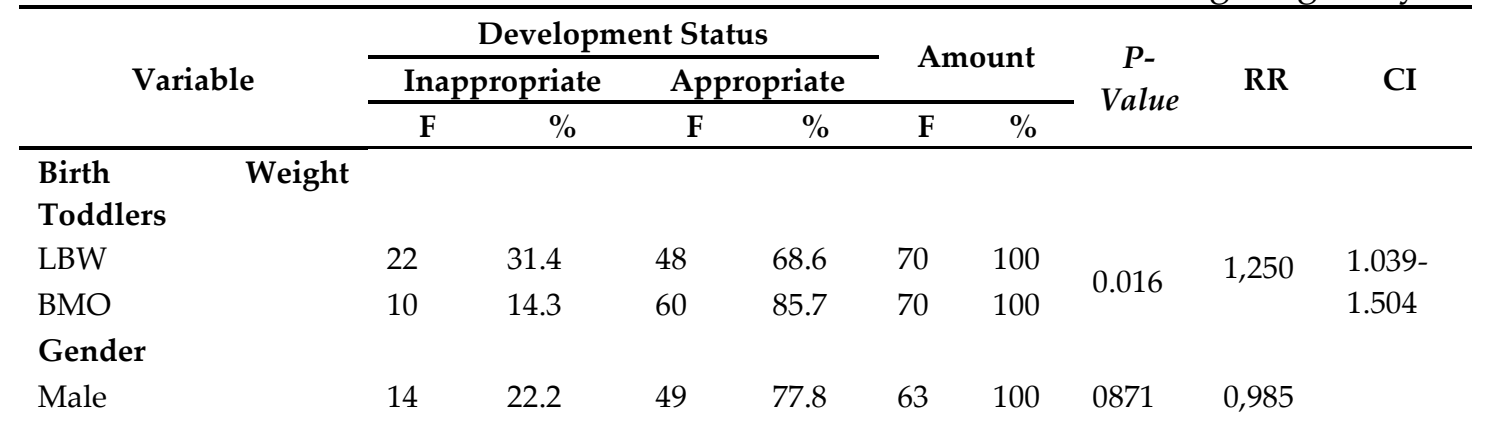




\begin{tabular}{|c|c|c|c|c|c|c|c|c|c|}
\hline Women & 18 & 23.3 & 59 & 76.7 & 77 & 100 & & & $\begin{array}{l}0.822- \\
1.180\end{array}$ \\
\hline \multicolumn{10}{|l|}{$\begin{array}{l}\text { Maternal education } \\
\text { level }\end{array}$} \\
\hline Low & 8 & 26.7 & 22 & 73.3 & 30 & 100 & \multirow{2}{*}{0575} & \multirow{2}{*}{1,066} & $0.841-$ \\
\hline High & 24 & 21.9 & 86 & 78.1 & 110 & 100 & & & 1.352 \\
\hline \multicolumn{10}{|l|}{ Parents ' income } \\
\hline Low & 1 & 50 & 1 & 50 & 2 & 100 & \multirow{2}{*}{0357} & \multirow{2}{*}{1,551} & $0.387-$ \\
\hline High & 31 & 22.5 & 107 & 77.5 & 138 & 100 & & & 6.219 \\
\hline \multicolumn{10}{|l|}{$\begin{array}{l}\text { Nutritional } \\
\text { mothers } \\
\text { pregnancy }\end{array}$} \\
\hline Chronic lack of energy & 13 & 36.1 & 23 & 63.9 & 36 & 100 & \multirow[b]{2}{*}{0.028} & \multirow[b]{2}{*}{1,279} & \multirow[b]{2}{*}{$\begin{array}{l}0.985- \\
1.662\end{array}$} \\
\hline $\begin{array}{l}\text { Non-chronic lack of } \\
\text { energy }\end{array}$ & 19 & 18.3 & 85 & 81.7 & 104 & 100 & & & \\
\hline
\end{tabular}

Based on the results of the study presented in table 2, toddlers aged 1-3 years who were male with incompatible development were 14 toddlers (22.2\%). Whereas toddlers with female sex with inappropriate development status were 18 toddlers (23.3\%). Chi-square test results show a p-value of $0.871(>0.05)$ which means there is no significant relationship between sex and the development of toddlers aged 1-3 years. This is in accordance with research conducted by Ayu, (2018) with results that show the value of $p(1,000)>0.05$, which means that there is no gender relationship to development in children aged 3-5 years. ${ }^{18}$ This is different from the results of research conducted by Aries (2017) which shows that developmental disorders occur more in toddlers with 34 children and 18 children. ${ }^{19}$ Soetjiningsih said boys are more often sick than girls, but this is not yet known the cause, the possible cause is chromosomal differences between boys (xy) and girls (xx). Physical and motor growth in men and women are different. Boys tend to be more active compared to girls. ${ }^{9}$ This statement is not in accordance with the results of research conducted at the Pleret Bantul Health Center. This discrepancy can be caused by differences in the characteristics of respondents and other factors that can affect the development of children under five such as the nutritional status of mothers during pregnancy, parental income, mother's education, and birth weight history of toddlers.

Table 2 shows that toddlers aged 1-3 years who are cared for by mothers with low education levels with inappropriate development as many as 8 toddlers (26.7\%). Whereas toddlers aged 1-3 years who are cared for by mothers with a high education level with inappropriate developmental status are 24 toddlers (21.9\%). Chi-square test results showed a p-value of $0.575(>0.05)$ which meant there was no significant relationship between the level of mother's education and the development of toddlers aged 1-3 years. The results of this study are consistent with research conducted by Rini, (2016) which shows that there is no significant relationship between maternal education and parity with the development of children under five. ${ }^{20}$ However, research conducted by Waqidil, 2014 shows different results, Waqidil states that there is a relationship between mother's educational level with the development of toddlers 3-5 years with @: 0,000< 0 : 0.05. ${ }^{21}$ Lestari, et al (2016) in their research stated that mother with low education is not easy to understand and understand the needs of children in supporting the development of children according to the stages of age while parents who are highly educated, better understand how to position themselves in the stages of child development. ${ }^{22}$ The results of research conducted at the Pleret Public Health Center 
did not show a relationship between maternal education and the development of toddlers because the number of respondents with low maternal education was only small at $21.4 \%$. In addition, other factors also affect the development of toddlers aged 1-3 years.

Based on table 2, toddlers aged 1-3 years who are cared for by low-income parents who experience developmental disorders as much as 1 toddler $(50.0 \%)$. Whereas toddlers aged 13 years who are cared for by high-income parents with inappropriate development status are 31 toddlers $(22.5 \%)$. Chi-square test results showed a p-value of $0.357(>0.05)$ which meant there was no significant relationship between parental income and the development of toddlers aged 1-3 years. This contrasts with research conducted by Lestari, et al (2016) which states that low socioeconomic status is significantly related to the development of children under five, and low socioeconomic status has a 4.4 times chance of development of children under five years of age compared to respondents with high socioeconomic status. ${ }^{22}$ The results of research at the Puskesmas Pleret Bantul show that there is no meaningful relationship between parental income and the development of toddlers, this is because the number of respondents with low incomes is very small, namely only two respondents.

Based on table 2, toddlers aged 1-3 years with the nutritional status of mothers during chronic lack of energy pregnancy who experienced inappropriate development status of 13 toddlers $(36.1 \%)$. As for toddlers with maternal nutritional status during pregnancy, not chronic lack of energy who experienced inappropriate development status as many as 19 toddlers $(18.3 \%)$. Chi-square test results showed a p-value of $0.028(<0.05)$, which means there is a significant relationship between birth weight with the status of the development of infants. This is consistent with the results of the study conducted by Yelmi, (2018) which states that there is a significant relationship between maternal nutrition during pregnancy with the development of infants with a p-value of $0.049(\mathrm{p}<0.05) .{ }^{23}$ Poor maternal nutrition during pregnancy often causes the baby to be born with LBW or stillbirth and rarely causes birth defects. Besides that, it also causes inhibition of fetal brain growth, anemia in newborns, infections, and abortion. ${ }^{9}$ The history of the nutritional status of pregnant women is an important factor in fetal growth and development. If there is a lack of nutritional status early in life it will have an impact on subsequent lives such as Stunted Fetal Growth (PJT), Low Birth Weight (LBW), small, short lean, low endurance, the risk of death, and impaired growth in infancy. ${ }^{24}$

Table 3. Logistic Regression Test of the Most Influential Variables with the Developmental Status of Toddlers Age 1-3 Years in the Pleret Health Center Area

\begin{tabular}{lllllll}
\hline \multicolumn{2}{c}{ Variable } & B & P-Value & $\mathbf{R r}$ & \multicolumn{2}{c}{$\begin{array}{c}\text { Convidence Interval } \\
\text { (CI) 95\% }\end{array}$} \\
\hline $\begin{array}{l}\text { Nutritional Status of mothers } \\
\text { during pregnancy }\end{array}$ & 0,793 & 0,072 & 2,210 & 0932 & 5,241 \\
\hline Birth Weight Toddlers & 0,910 & 0,036 & 2,484 & 1,059 & 5,829 \\
\hline
\end{tabular}

Statistical test results with logistic regression revealed that the nutritional status of mothers during pregnancy had a p-value of 0.072 with a RR of 2.21 and the birth weight of children under five had a p-value of 0.036 with a RR of 2.484 . This shows that the most influencing the developmental status of children under five are the birth weight of children under five with a p-value of $0.036<0.05$, toddlers with a history of low birth weight are 2,248 times more at risk of developing developmental disorders compared to toddlers with a history of normal birth weight. 


\section{Path Analysis}

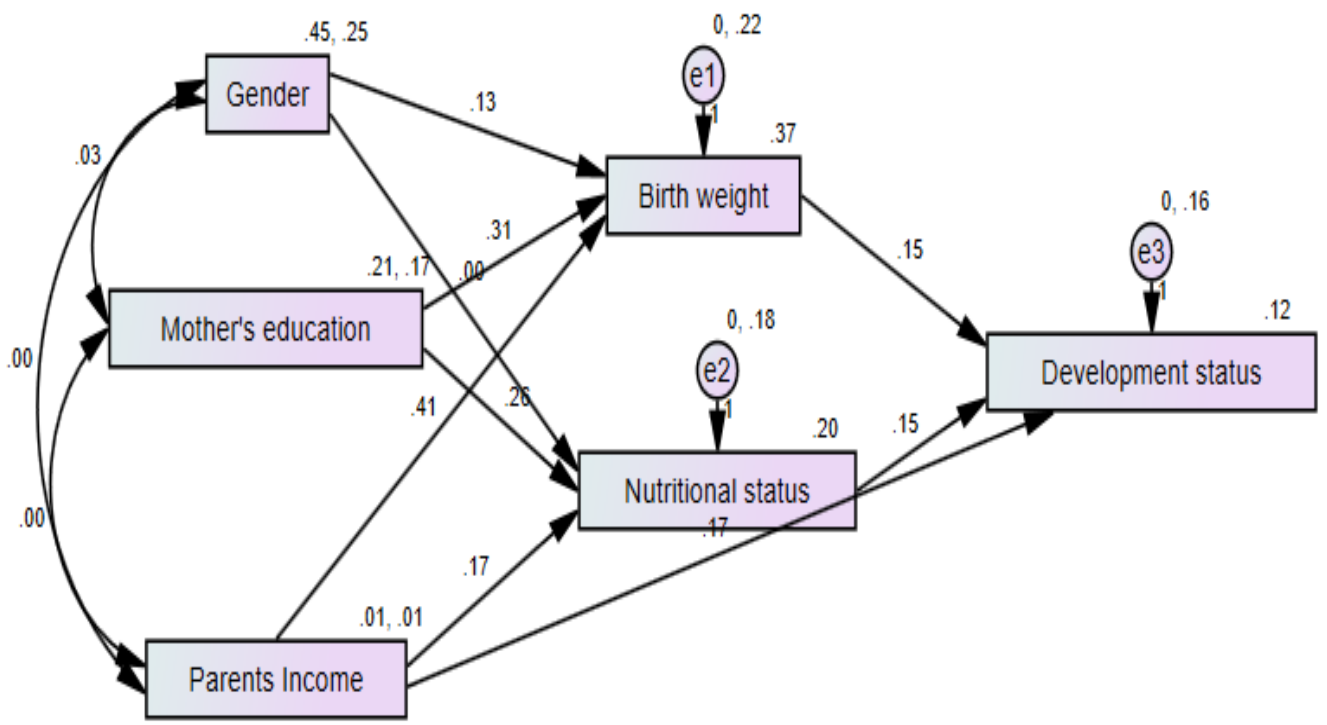

Picture 1. Structural Model

Figure 1 shows that the structural model has been completed using IBM SPSS AMOS. The result indicator shows that the variables under study have the suitability of the path analysis model (goodness of fit measure). The results show that there is a measurement of model fit that shows a CMIN fit index of 1.932 with a $\mathrm{p}$ value $=0.587>0.05$; NFI (Normed fot Index) $=$ 0.951; > 0.90; CFI (Comparative fit index) $=1.000>0.90$; RMSEA (Root Mean Square Error of Approximation $)=0.108<0.080$, which means the empiric model. The results can be seen in table 4 below:

Table 4. Results of Path Analysis of factors related to development of children aged 1-3 years

\begin{tabular}{|c|c|c|c|c|c|c|}
\hline Dependent Variable & & Independent Variable & $\mathbf{b}^{*}$ & SE & p & $\beta^{* *}$ \\
\hline $\begin{array}{l}\text { Direct Influence } \\
\text { Development status } \\
\text { Development status } \\
\text { Development status } \\
\text { Indirect Influence } \\
\text { Birth weight } \\
\text { Birth weigh } \\
\text { Nutritional status } \\
\text { Birth weigh } \\
\text { Nutritional status } \\
\text { Nutritional status } \\
\text { N observation: } 140 \\
\text { Model Fit } \\
\text { CMIN : } 1,932 \\
\text { p value : } 0,587 \\
\text { NFI : } 0,951 \\
\text { CFI : } 1.000\end{array}$ & $\begin{array}{l}\leftarrow \\
\leftarrow \\
\leftarrow \\
\leftarrow \\
\leftarrow \\
\leftarrow \\
\leftarrow \\
\leftarrow \\
\leftarrow \\
\leftarrow\end{array}$ & $\begin{array}{l}\text { Parent income } \\
\text { Birth weigh } \\
\text { Nutritional status } \\
\text { Gender } \\
\text { Mother's education } \\
\text { Parent income } \\
\text { Parent income } \\
\text { Mother education } \\
\text { Gender }\end{array}$ & $\begin{array}{l}0,126 \\
0,311 \\
0,170 \\
0,411 \\
0,263 \\
-0,004\end{array}$ & $\begin{array}{l}0,081 \\
0,099 \\
0,303 \\
0,340 \\
0,088 \\
0,073\end{array}$ & $\begin{array}{l}0,001 \\
<0,01 \\
0,001 \\
0,001 \\
0,001 \\
0,001\end{array}$ & $\begin{array}{l}0,126 \\
0,255 \\
0,046 \\
0,097 \\
0,247 \\
-0,05\end{array}$ \\
\hline
\end{tabular}


Table 3 shows that there is a direct influence between the variables of parents' income, birth weight, and nutritional status on child development. every increase of one unit of parent's income, it will increase the child's development by 0.165 units $(b=0.165, \mathrm{SE}=0.292, \mathrm{p}=0.001)$. Each one unit increase. Every increase of one unit of birth weight will increase child development by 0.146 units $(b=0.146)$ and every increase of one unit of nutritional status will increase child development by 0.148 units $(b=0.148)$. Meanwhile, gender and parental education have an indirect effect on the development of children aged 1-3 years through intermediate variables, namely nutritional status and birth weight.

Based on the logistic regression test results outlined in table 4, the results show that the nutritional status of mothers during pregnancy has a p-value of 0.072 and the birth weight of children under five has a $\mathrm{p}$-value of 0.036 . This shows that the most closely related to the status of the development of infants is the birth weight of infants with a p-value of $0.036<0.05$. The development of toddlers is greatly influenced by the condition of body weight at birth. Children born with LBW are at risk of experiencing problems in their development ${ }^{17}$. LBW babies increase the risk of motor developmental disorders related to the ability to walk, and when compared to normal babies, LBW babies are weak in fine motor skills such as breaking down threads. ${ }^{8}$

\section{Conclusion}

Based on the exposure of the above research results, the conclusions that can be drawn include that most of the children under five have appropriate developmental status LBW history has a significant relationship with the development of toddlers aged 1-3 years. Toddlers with a history of LBW are more at risk of developing developmental disorders in toddlers. Toddlers with a history of low birth weight are more likely to experience developmental abnormalities compared to toddlers with a history of normal birth weight there is a direct influence between the variables of parents' income, birth weight, and nutritional status on child development.

\section{Reference}

1. Prawiroharjo S. Buku Acuan Nasional Pelayanan Kesehatan Maternal Dan Neonatal. Edisi Ke 5. (Saifudin A, ed.). Jakarta: Bina Pustaka Sarwono Prawiroharjo; 2009.

2. WHO. Infant Newborn. 2015. www.who.int/topics/infant_newborn/en/.

3. Manuaba. Ilmu Kebidanan, Penyakit Kandungan, Dan KB. Jakarta: Penerbit Buku Kedokteran EGC; 2010.

4. UNICEF. Inequities in Early Childhood Development What the data say.

5. Kemenkes. Pentingnya Pemantauan Kesehatan Pada Masa Periode Emas Balita. Jakarta: Kemenkes RI; 2015.

6. $\quad$ Kemenkes. Riset Kesehatan Dasar. Jakarta: Kemenkes RI; 2018.

7. Bantul D. Profil Kesehatan Kabupaten Bantul. Dinas Kesehatan Kabupaten Bantul; 2019. 